\title{
SISTEM DOKUMENTASI PENGELOLAAN LIMBAH CAIR BERACUN DAN BERBAHAYA (B3) DI LABORATORIUM JASA UJI
}

\author{
Tia Amina Setiawati ${ }^{1}$, Endah Wulandari ${ }^{2}$, Komarudin $^{3}$, Euis Desniati ${ }^{4}$ \\ ${ }^{1}$ Laboratorium Jasa Uji Fakultas Teknologi Industri Pertanian Universitas Padjadjaran. \\ Email : t.amina.setiawati@unpad.ac.id \\ ${ }^{2}$ Prodi Teknologi Industri Pangan FTIP UNPAD \\ ${ }^{3}$ Prodi Teknik dan Manajemen Industri Pertanian FTIP UNPAD \\ ${ }^{4}$ Fakultas Teknologi Industri Pertanian UNPAD
}

\begin{abstract}
ABSTRAK
Laboratorium sebagai sarana utama dalam kegiatan tri darma perguruan tinggi, menghasilkan limbah beracun dan berbahaya (B3). Limbah B3 tersebut selalu bertambah setiap harinya sehingga perlu dibuatkan sistem pengelolaannya. Laboratorium jasa Uji FTIP sebagai laboratorium layanan pengujian pangan melayani 28 jenis parameter uji kimia, menghasilkan 22 jenis limbah cair B3. Sebagai langkah awal pengelolaan, perlu dibuatkan sistem pendokumentasian agar pendataan terhadap limbah bisa lebih tertata. Pada penelitian ini, pendokumentasian pengelolaan limbah dikhususkan untuk limbah cair B3 yang dihasilkan oleh laboratorium jasa Uji yang berada di lingkungan Fakultas Teknologi Industri Pertanian Universitas Padjadjaran. Sistem dokumentasi limbah cair B3 berdasarkan bahan dasar penyusun limbah yang pendokumentasiannya disesuaikan dengan yang tertera pada dokumen KAN-P-15, tentang Pedoman Teknis untuk Pengelolaan Limbah Laboratorium untuk Akreditasi Laboratorium Lingkungan. Hasil pendokumentasian telah dapat mengelompokkan limbah cair B3 menjadi 6 kelompok, yaitu $A$ (kelompok yang mengandung pelarut organik, 50\%), B (kelompok yang mengandung sianida, 4,5\%), C (kelompok yang mengandung Fluorida dan Fosfor,9,1\%), $F$ (kelompok yang mengandung logam berat, 4,5\%), G (kelompok yang mengandung asam dan basa, 22,7\%) dan $H$ (kelompok yang mengandung senyawa lainnya, 9,1\%). Pendokumentasian ini memudahkan dalam pengelompokkan dan pendataan limbah.
\end{abstract}

Keywords : Laboratorium; limbah cair B3; pengelolaa; sistem pendokumentasian.

\section{PENDAHULUAN \\ Latar Belakang}

Sejalan dengan aktivitas laboratorium yang terus menerus melayani pengujian dalam rangka Tri Dharma Perguruan Tinggi, yaitu praktikum, penelitian dan pengabdian, sudah tentu akan terjadi peningkatan jumlah limbah cair Bahan Beracun dan Berbahaya (B3) yang dihasilkannya. Dalam melayani pengabdian kepada masyarakat Laboratorium Jasa Uji (LJU) melayani pengujian di bidang hasil pertanian. Parameter pengujian yang dapat dilayani oleh LJU meliputi parameter fisik (tekstur, warna, viskositas, berat jenis), parameter kimia ( uji kadar protein metode kjeldahl, uji gula, tannin, lemak, kadar air, mineral dII), parameter mikrobiologi ( total bakteri, kapang, bakteri salmonella dII) serta parameter organoleptik dan uji masa simpan produk pangan. Sejak tahun 2016 LJU menempati gedung baru di kompleks gedung Fakultas Teknologi Industri Pertanian (FTIP) setelah sebelumnya menempati gedung lama di Fakultas Pertanian, telah melayani pengujian sebanyak 1076 sampel pada tahun 2016 dan 1320 sampel pada tahun 2017. Parameter pengujian kimia termasuk yang dominan diujikan, yaitu sebesar $62,74 \%$ di tahun 2017, sehingga jumlah limbah cair B3 yang dihasilkan dari proses pengujiaan setiap harinya selalu bertambah selain 
kegiatan praktikum dan penelitian. Data jumlah sampel dan jumlah sampel dengan pengujian parameter kimia di tahun 2017 dapat dilihat pada gambar 1 berikut ini.

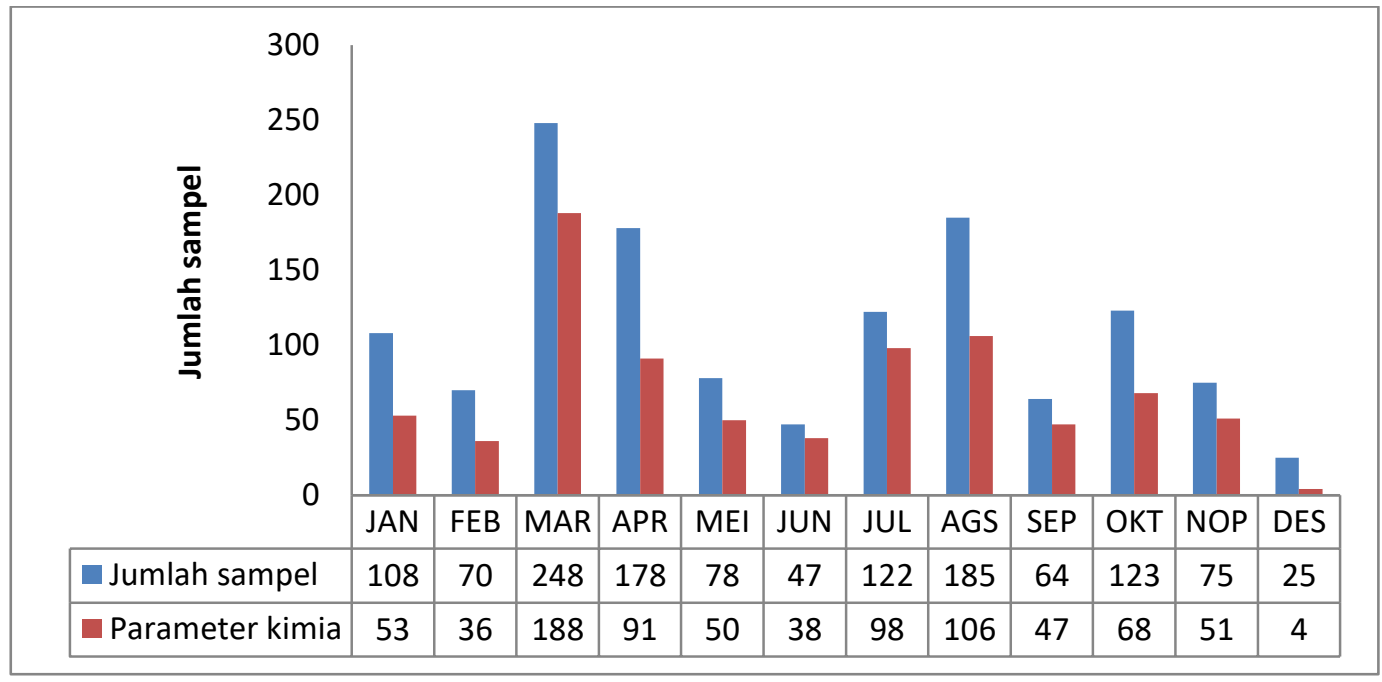

Gambar 1. Data Sampel Lab Jasa UJi FTIP tahun 2017

( sumber : back up data LJU tahun 2017)

Limbah B3 terdiri dari limbah padat (endapan sisa pereaksi, kertas saring, media agar, kertas tisu, kertas timbang, dan lain-lain), dan limbah cair berupa larutan hasil reaksi ataupun sisa pereaksi. Sejak menempati gedung baru, penyimpanan limbah B3 belum dibuatkan sistem pendokumentasianya, belum ada penataan limbah, limbah hanya ditampung, dilabeli dan diletakan seadanya saja, sehingga perlu dibuatkan suatu sistem dokumentasi yang lebih baik agar selama proses penyimpanan sementara sampai tiba saatnya di angkut untuk dikelola lebih lanjut berlangsung aman.

Menurut Undang-undang Republik Indonesia No 32. Tahun 2009, yang dimaksud dengan Bahan beracun dan Berbahaya (B3) adalah zat, energy, dan/atau kompenen lain karena sifat, konsentrasi, dan/atau jumlahnya, baik secara langsung maupun tidak langsung dapat mencemarkan dan/atau merusak lingkungan hidup, dan/atau membahayakan lingkungan hidup, kesehatan serta kelangsungan hidup manusia dan makhluk lain. Sehingga diperlukan perlakuan khusus dalam menangani buangan hasil laboratorium sebelum dibuang ke saluran air (Putri, 2012). Karakteristik limbah B3 dapat diketahui dari sumber prosesnya, bahan kimia penyusunnya dan selanjutnya ditentukan karakter dari limbah itu sendiri melalui suatu proses. Karakteristik limbah B3 menurut (Brawijaya, 2015) adalah sebagai berikut :mudah meledak (explosive), misalnya bahan peledak, mudah terbakar (flammable) seperti bahan bakar atau pelarut organik, bersifat reaktif misalnya bahan-bahan oksidator, bersifat korosif seperti asam kuat, bersifat infeksius, biasanya limbah bakteri, rumah sakit, bersifat irritant, misalnya basa kuat, berbahaya (Harmfull), seperti logam berat, beracun , seperti HCN, Cr (IV), karsinogenik, mutagenic, teratogenik, seperti merkuri, turunan benzene, bahan radioaktif, seperti Uranium, Plutonium 
Dalam dokumen KAN P-15, tahun 2009, tentang pedoman teknis untuk pengelolaan limbah laboratorium untuk akreditasi laboratorium lingkungan, limbah B3 dikatagorikan ke dalam 8 katagori, yaitu kategori $A$ (pelarut organik), B( sianida), C(Fluorida dan phosphor), $\mathrm{D}$ (Merkuri/raksa), $\mathrm{E}$ (asam kromat), $F$ (logam berat), $G$ (asam dan basa), dan $\mathrm{H}$ (lain-lain).

\section{Sistem Dokumentasi Limbah}

Pengelolaan limbah B3 merupakan suatu rangkaian kegiatan yang mencakup penyimpanan, pengumpulan, pemanfaatan, pengangkutan, dan pengolahan limbah B3 termasuk penimbunan hasil pengolahan tersebut. Dalam rangkaian kegiatan tersebut terkait beberapa pihak yang masingmasing merupakan mata rantai dalam pengelolaan limbah B3, yaitu: penghasil Limbah B3, pengumpul Limbah B3, pengangkut Limbah B3, pemanfaat Limbah B3;pengolah Limbah B3, penimbun Limbah B3 (Sidik,2012). Laboratorium sebagai penghasil limbah B3 harus mempunyai sistem dokumentasi yang baik agar ketika limbah masih disimpan di tempat penyimpanan sementara, tersedia data yang memadai mengenai identitas limbah. Data ini diperlukan dalam rangka inventaris limbah B3 yang ada. Selama ini di LJU, limbah telah di tampung dalam wadah jarigen dan dilabeli berdasarkan jenis parameter analisis. Perlu dilakukan inventarisasi secara berkala terhadap limbah B3, jenis dan jumlahnya.

Komite Akreditasi Nasional (KAN) telah menyusun pedoman teknis pengelolaan limbah B3 bagi laboratorium lingkungan, yang tertuang dalam dokumen no KAN P-15, tahun 2009. Dokumen ini dapat dijadikan salah satu acuan dalam pengelompokkan limbah, sehingga limbah dapat didokumentasikan berdasarkan pengelompokkan tersebut.

\section{Tujuan, Metode penelitian}

Tujuan penelitian ini adalah membuat suatu sistem dokumentasi terhadap limbah cair B3 yang dihasilkan oleh LJU untuk memudahkan dalam inventarisasi secara berkala terhadap limbah B3 yang dihasilkan.

Metode penelitian yang diterapkan adalah studi literatur, penyusunan formulir pengelompokan limbah, pengisian data tentang limbah berdasarkan kelompok, dan pengelompokan limbah mengacu pada dokumen KAN P-15 tentang pedoman teknis pengelolaan limbah B3 pada laboratorium lingkungan. Dari data pengelompokkan tersebut juga dapat diketahui sifat limbah sehingga dapat diberi label tanda bahaya, yang sangat berguna dalam proses penyimpanan, pengangkutan dan pengelolaan selanjutnya. Diagram tahap penelitian dapat dilihat pada gambar 2 berikut ini :

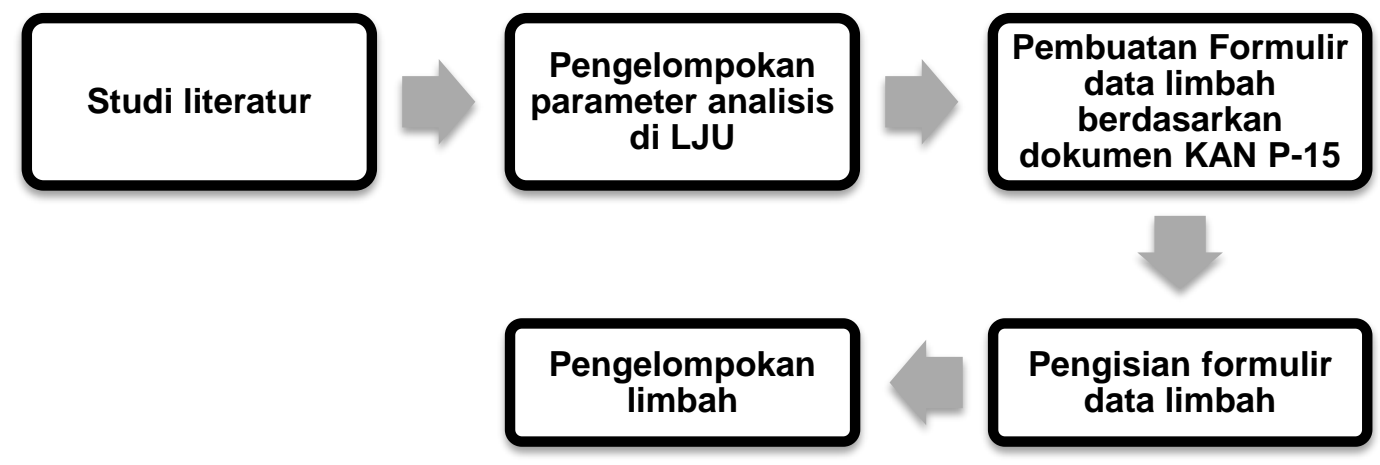

Gambar 2. Diagram alir penelitian 


\section{T. A. Setiawati dkk./ Vol 1 (2) 2019, 41-48}

\section{HASIL DAN PEMBAHASAN}

Analisis terhadap limbah yang dihasilkan dari parameter analisis

Data yang diperoleh dari jenis parameter analisis kimia yang dapat dilayani oleh LJU FTIP yaitu sebanyak 22 parameter analisis, diantaranya adalah uji proksimat untuk bahan pangan, uji kualitas madu seperti aktivitas enzim diastase, $\mathrm{HMF}$, dan gula, uji protein metode kjedahl dan spektrofotometri (Lowry dan Biuret), uji pati, total gula dan gula pereduksi, uji keamanan pangan seperti pemanis, boraks dan formalin, uji vitamin B dan C, dan lain sebagainya. Dari parameterparameter analisis tersebut, kita dapat mengelompokan jenis limbah B3 yang dihasilkan. Pengelompokkan tersebut dapat dilihat dari jenis bahan kimia penyusun limbah, yaitu dari pereaksipereaksi yang digunakan dalam analisis.

\section{Pembuatan formulir data limbah}

Untuk memudahkan pendataan terhadap limbah B3 yang dihasilkan, perlu dibuatkan formulir khusus yang dapat dengan mudah diisi dan sekaligus dikelompokan. Pada dokumen KAN P15, tahun 2009 seperti telah dijelaskan diatas terdapat 8 kategori limbah,yaitu kategori $A$ (pelarut organik), $B$ ( sianida), C(Fluorida dan phosphor), $D$ (Merkuri/raksa), $E$ (asam kromat), $F$ (logam berat), $G$ (asam dan basa), dan $\mathrm{H}$ (lain-lain). Formulir dibuat dengan mengikuti alur dari diagram katagori limbah, jadi PLP/ petugas pendata limbah dapat dengan mudah mengisi lalu mengelompokan limbah tersebut. Diagram alir limbah dapat dilihat pada gambar 3 berikut ini:

DLAGRAMT ALTR PEMWUANGAN LIMWATI

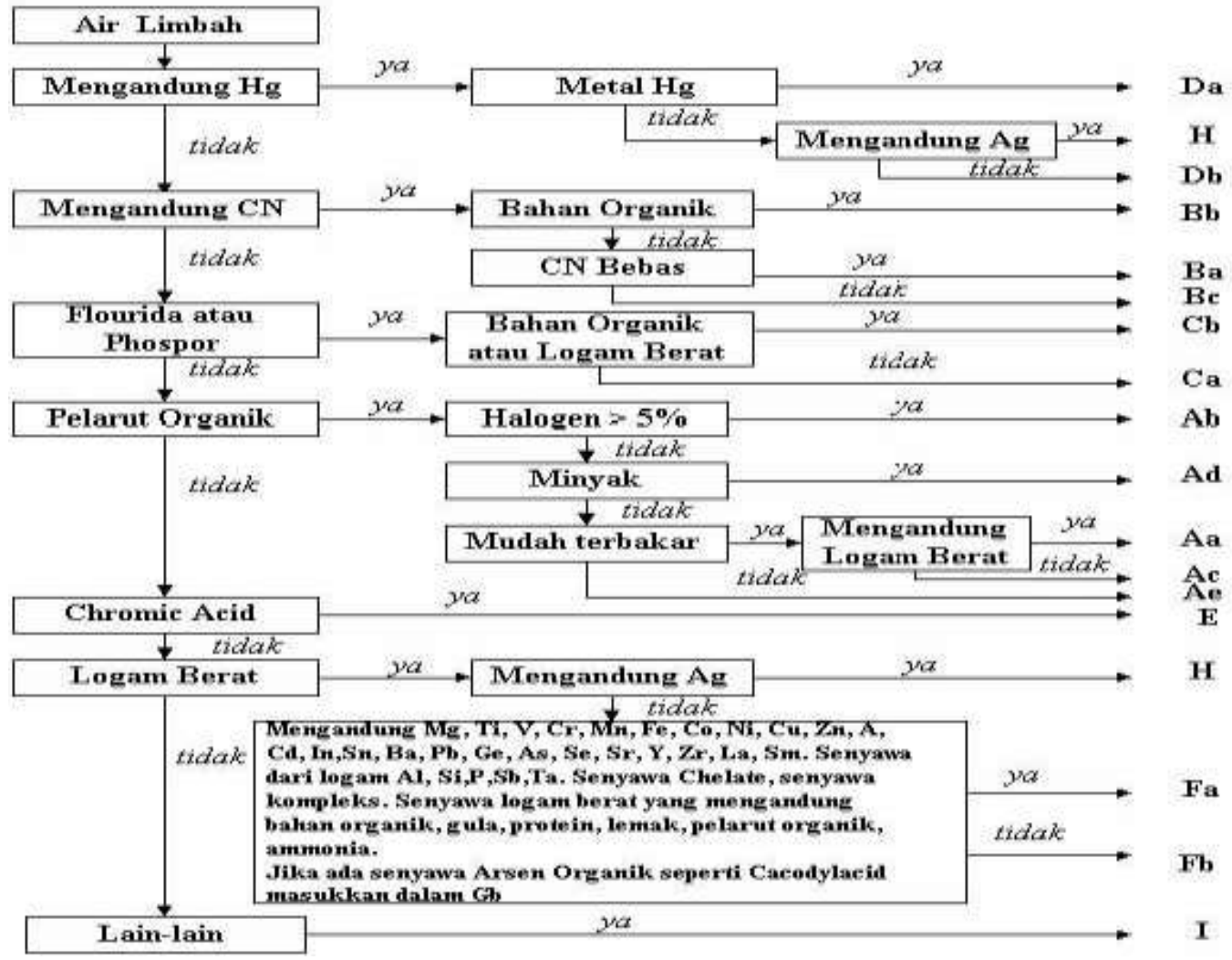

Gambar 3. Diagram alir limbah 
Dari diagram pada Gambar 3, berikut (gambar 4) : dibuatkan formulir data limbah sebagai

PENGELOLAAN LIMBAH CAIR BAHAN BERACUN DAN BERBAHAYA

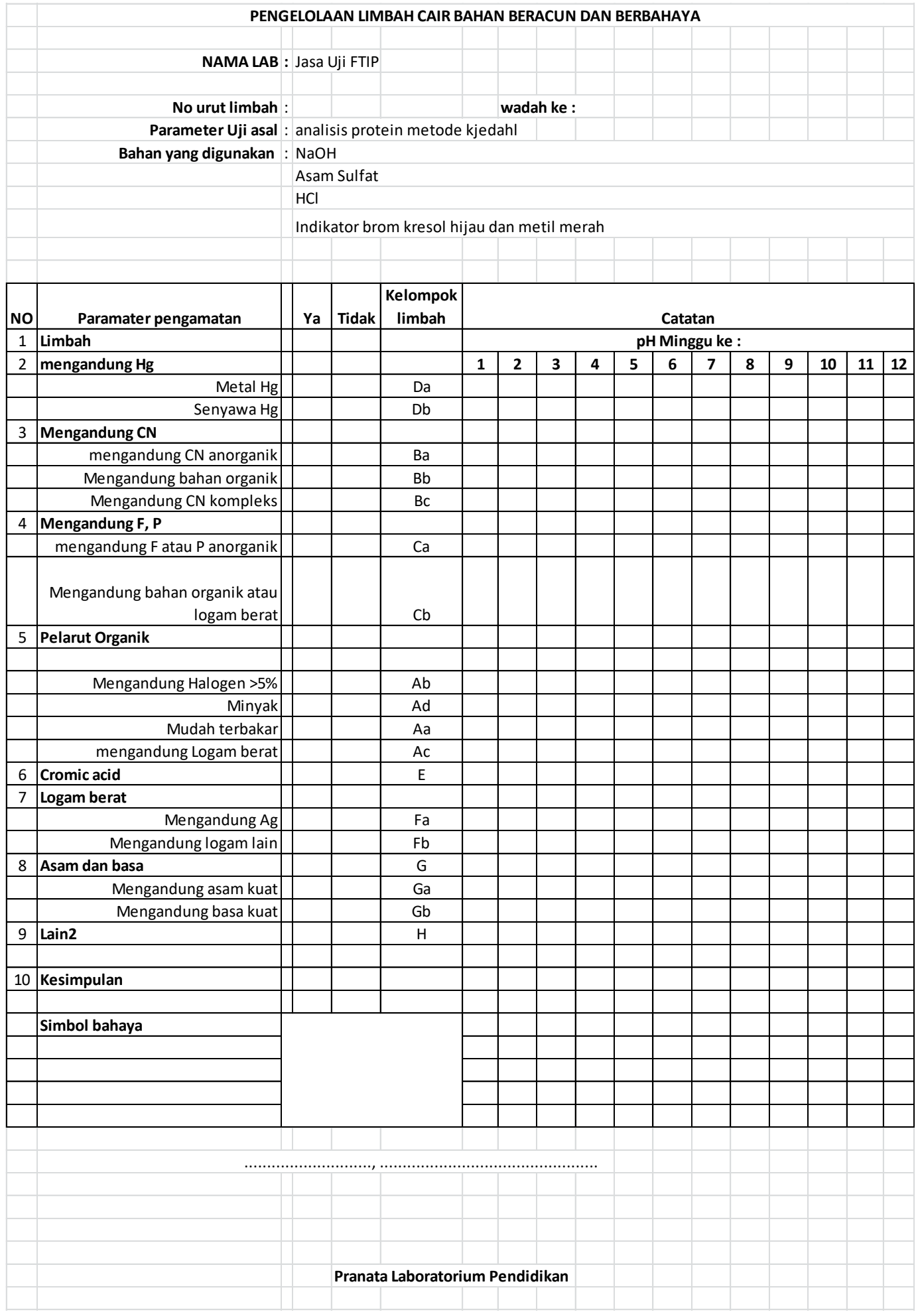

Gambar 4(a) Formulir Data Pengelolaan Limbah Cair 


\section{PENGELOLAAN UIMBAH CAIR BAHAN BERACUN DAN BERBAHAYA}

NAMA LAB : Jasa Uji FTIP

No urut limbah : Lc /6/001 wadah ke: 1

Parameter Uji asal : analisis protein metode kjedahl

ahan yang digunakan : $\mathrm{NaOH}$

Asam Sulfat

$\mathrm{HCl}$

Indikator brom kresol hijau dan metil merah

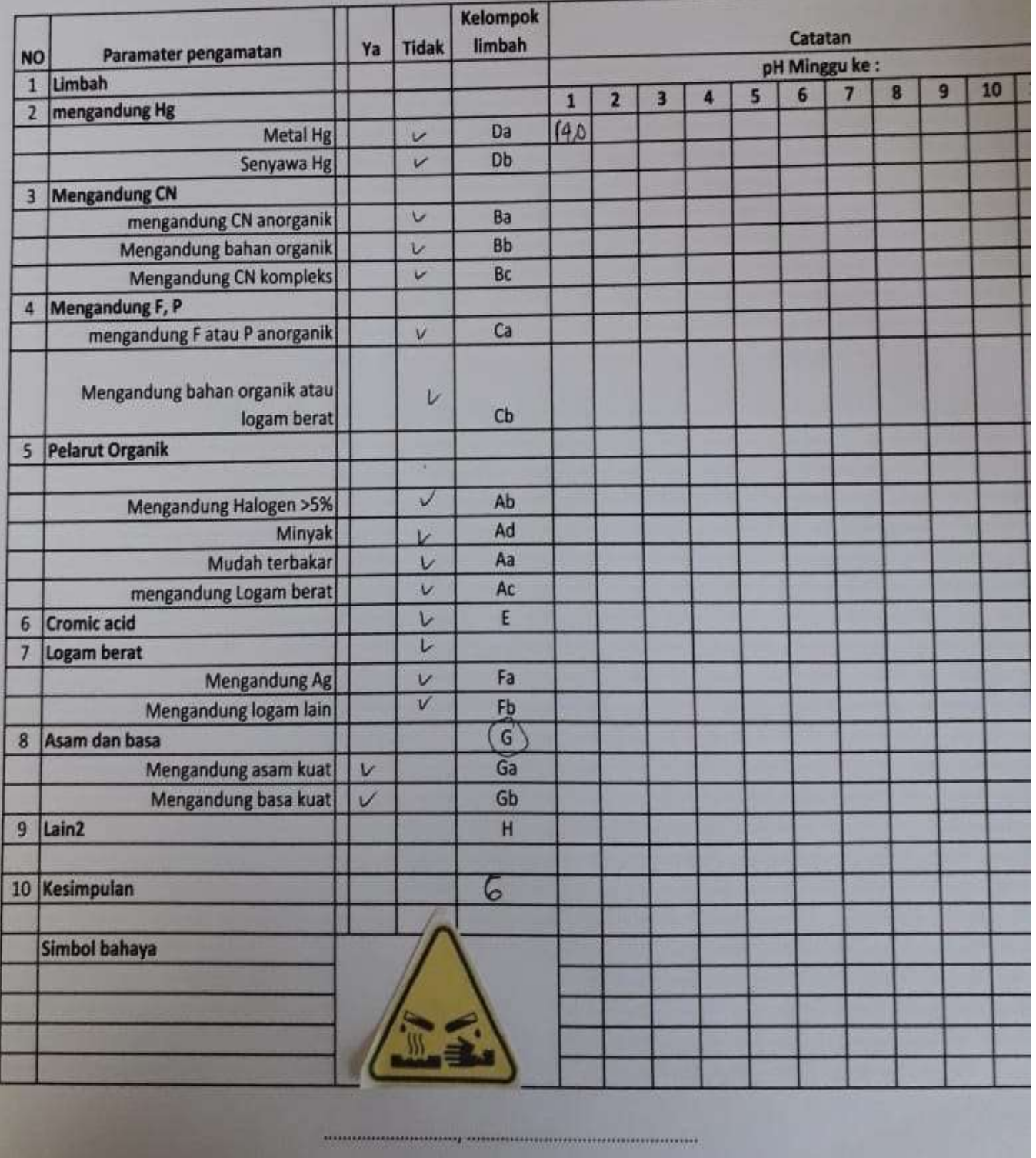

Gambar 4 (b) Formulir data limbah LJU 


\section{T. A. Setiawati dkk./ Vol 1 (2) 2019, 41-48}

Dari formulir yang telah dibuat dan kemudian diisi data mengenai limbah per jenis parameter analisis yang dapat dilayani LJU, dilihat dari bahan kimia penyusunnya.

\section{Pengelompokan limbah}

Dari formulir data limbah Limbah cair B3 yang ada di lab LJU yang dihasilkan dari 22 parameter analisis kimia, dapat dikelompokkan menjadi 6 kelompok limbah, yaitu Kelompok A sebanyak 11 parameter analisis (50\%), yang dibagi dalam 4 sub katagori, yaitu $\mathrm{Aa}$ (pelarut organik dan mudah terbakar $=31,82 \%$ ), $A b$ (pelarut organik yang mengandung halogen $=4,55 \%$, Ac(pelarut organik yang mengandung logam berat $=4,55 \%)$, dan $\mathrm{Ad}($ pelarut organik yang mengandung minyak $=9,09 \%$ ). Kelompok katagori $B$ limbah yang mengandung senyawa sianida sebanyak 1 parameter analisis yaitu sub kelompok $\mathrm{Ba}$ (sianida anorganik $=4,55 \%$ ). Kelompok katagori $C$ limbah yang mengandung fluorida dan fosfor sebanyak 2 parameter analisis yaitu sub kelompok $\mathrm{Ca}$ (fluorida atau fosfor anorganik $=9,09 \%$ ). Kelompok katagori $F$, limbah yang mengandung logam berat sebanyak 1 parameter analisis, dengan sub katagori $\mathrm{Fb}$ (logam berat yang mengandung bahan organik=4,55\%). Kelompok katagori $\mathrm{G}$, limbah yang mengandung asam dan basa, sebanyak 5 parameter analisis, dengan sub katagori $\mathrm{Ga}$ (asam kuat $=9,09 \%$ ), Gb (basa kuat=9,09\%). Kelompok terakhir adalah limbah yang tidak termasuk kelompok A-G, yang di katagorikan dengan limbah yang mengandung senyawa lain $(H=9,09 \%, 2$ parameter analisis). Data grafik kelompok katagori limbah dapat dilihat pada gambar 5 dan 6 berikut ini.

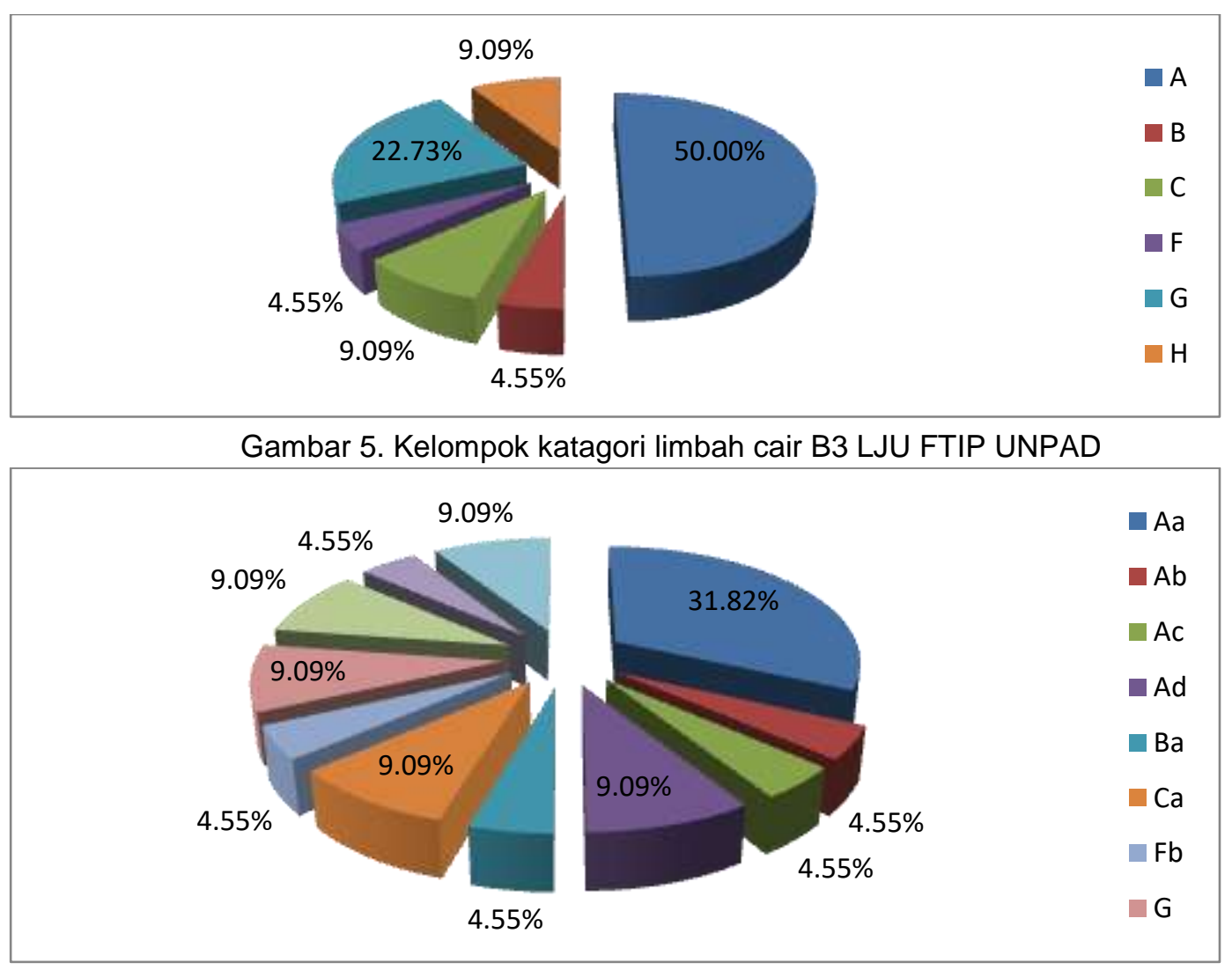

Gambar 6. Kelompok sub katagori limbah cair B3 LJU FTIP UNPAD 
Dokumentasi label kemasan
penampung limbah
Selain dibuatkan formulir data limbah, label kemasan penampung limbah cair B3 juga harus diperbaiki. Pada penelitian ini dibuatkan label kemasan yang baru, yang dapat menggambarkan identitas limbah. Label kemasan penampung limbah yang telah dibuat selain berupa label hardcopy yang menempel pada kemasan, juga dibuatkan barcode yang dapat discan dan di buka link identitas limbah secara online, sehingga memudahkan dalam pemeriksaan saat penyimpanan limbah. Contoh gambar label dapat dilihat pada gambar 7 berikut ini.

\begin{tabular}{|l|l|l|}
\hline \multicolumn{3}{|c|}{$\begin{array}{l}\text { LIMBAH CAIR BAHAN BERACUN } \\
\text { DAN BERBAHAYA (B3) }\end{array}$} \\
\hline $\begin{array}{l}\text { No Urut limbah } \\
\text { Kode } \\
\text { kelompok }\end{array}$ & $:$ & LC/A/001 \\
\hline $\begin{array}{l}\text { Bahan } \\
\text { penyusun }\end{array}$ & $:$ & $\begin{array}{l}\text { NaOH,Asam sulfat,HCI,Indikator } \\
\text { bromkresol hijau dan metil merah }\end{array}$ \\
\hline Nama Lab & $:$ & Jasa Uji \\
\hline Simbol bahaya & $:$ &
\end{tabular}

Gambar 7. Label kemasan penampung limbah

\section{KESIMPULAN}

Sistem dokumentasi limbah cair B3 yang telah diterapkan di LJU FTIP UNPAD telah dapat mengelompokkan limbah cair B3 yang dihasilkan kedalam 6 kelompok katagori limbah, yaitu A (kelompok yang mengandung pelarut organik, 50\%), B (kelompok yang mengandung sianida, 4,5\%), C (kelompok yang mengandung Fluorida dan Fosfor,9,1\%), $F$ (kelompok yang mengandung logam berat, 4,5\%), G (kelompok yang mengandung asam dan basa, 22,7\%) dan $\mathrm{H}$ (kelompok yang mengandung senyawa lainnya, 9,1\%). Sistem dokumentasi pada label juga memudahkan dalam penyimpanan dan untuk selanjutnya pengangkutan limbah.

\section{SARAN}

Perlu dibuatkan sistem terpadu dari mulai penghasil limbah (laboratorium), penyimpanan sementara, pengangkut limbah sampai pengelola limbah di tingkat Universitas.

\section{UCAPAN}

TERIMAKASIH

Penelitian ini dibiayai oleh program Riset Tenaga Kependidikan Universitas Padjadjaran (RTKU) Hibah Internal UNPAD(HIU) tahun 2018.

\section{DAFTAR PUSTAKA}

Brawijaya, U. 2015. Hazardous Waste Sanitasi Dan Pengolahan Limbah.

Komite Akreditasi Nasional. 2009. Pedoman Teknis untuk Pengelolaan Limbah Laboratorium untuk Akreditasi Laboratorium Lingkungan. Jakarta

Putri, A. A. 2012. Desain Pengolahan Limbah Kimia Laboratorium Dengan Prinsip Reduce, Reuse, Dan Recycle (Studi Di Fakultas Tarbiyah lain Walisongo Semarang). 27-31.

Sidik, A.A, Damanhuri,E. 2012. Studi Pengelolaan Limbah B3 (Bahan beracun dan berbahaya) Laboratorium-Laboratorium di ITB. Jurnal Teknik Lingkungan. Volume 18 No 1 12-20. Bandung. 